\title{
Statement of Retraction
}

\section{Article title: "Hemopneumothorax associated with pneumorrachis following blunt chest trauma"}

Authors: Putu Eka Mardhika, Tjokorda Gde Bagus Mahadewa, Citra Aryanti

Bibliometrics: Volume 2, Issue 2, pages 33-36

DOI: $10.36444 / \mathrm{nsmc} . \mathrm{v} 2 \mathrm{i} 2.10$

Neurologico Spinale Medico Chirurgico with Indoscholar is retracting the paper titled "Hemopneumothorax associated with pneumorrachis following blunt chest trauma" by Putu Eka Mardhika, Tjokorda Gde Bagus Mahadewa, Citra Aryanti, published in Volume 2, Issue 2, pages 33-36. Upon investigation, it was determined that a similar article, titled the same was submitted by the authors and simultaneously published in another journal (redundant publication)

As a result, the article published in Neurologico Spinale Medico Chirurgico has been retracted and should not be cited in the electronic or print version of the journal.

\section{Publication History}

Received: 2019-09-15

Accepted: 2019-09-15

Published: 2019-09-15

Retracted: 2020-09-15 